\title{
Semiotic Study in the Kirab of Tuk Si Bedug Traditional Ceremony
}

\author{
Sherly Fransisca ${ }^{1}$, Hajar Pamadhi $^{1}$
}

\author{
${ }^{1}$ Arts Education Study Program, Graduate School, Yogyakarta State University, Yogyakarta 55281, Indonesia \\ *Corresponding author.Email: Franc.sherly@gmail.com
}

\begin{abstract}
This study aimed to examine the signs in the Kirab of Tuk Si Bedug traditional ceremony in the current hyperreality age. Kirab is a part in the series of Tuk Si Bedug traditional ceremony at Margodadi village, Seyegan, Sleman. This study employed Jean Francois Lyotard's semiotics which unravels fragmentations in a small narrative deeper, playing between language and art. This study also offers information on the facts behind the Kirab tradition in the millennial or current hyperreality age involving media to share information and consumptive behavior in the traditional ceremony.
\end{abstract}

Keywords : Kirab Tuk Si Bedug, Lyotard's Semiotics, the age of hyperrealist

\section{INTRODUCTION}

The Tuk Si Bedug Traditional Ceremony is a series of traditional ceremonies among the people of Margodadi village, Seyegan, Sleman. The ceremony, which is carried out from generation to generation, is usually held on Friday Pahing between June and August during the dry season. The Tuk Si Bedug traditional ceremony is a form of people's transcendence of their gratitude to the creator for all the abundant blessings. This tradition is also a tribute to Sunan Kalijaga, who is believed to initiate the spread of Islam in the village of Margodadi.

Although this ceremony has undergone a metamorphosis or transformation since the ancient times, the meaning in the ceremony remains true. In the past, this traditional ceremony was held simply for the local population to enjoy. Nowadays, this ceremony is being held in a festive manner and supported by the local government to attract many tourists.

The Tuk Si Bedug traditional ceremony includes a series of events. One of the series of events at the Tuk Si Bedug traditional ceremony is the kirab, which is an intriguing topic. The Kirab incites various interpretations by many parties. Today's society are inclined to be individualistic and view Kirab in the Tuk Traditional Ceremony in various perspectives. in the People not only view kirab in terms of its reality but also interpret it beyond the reality itself. Things beyond one's instincts such as mythical, spiritual, and ideological values on these cultural phenomena make them interesting. Based on this description, this paper attempts to explore more about the signs contained in the Kirab at the Tuk Traditional Ceremony then discussing it further about what is behind the tradition associated with the concept of hyperreality.

\section{LITERATURE REVIEW}

\subsection{Kirab}

Kirab at the Tuk Traditional Ceremony is one of the events that the community looks forward to the most. Kirab refers to the parade of a group of people walking together hand in hand in an order of front to back in a series of ceremony [7]. In the Tuk Si Bedug ceremony, kirab is carried out with a parade of arakan carrying gunungan. Gunungan is a triangleshaped object which resembles a mountain, also known as kekayon or kayon [2], meaning "to swing," and refers to the tree of life or Kalpataru. The pointed shape of Gunungan is aimed to remind the people that all things will return to the creator, or in Javanese Sangkan Paraning Dumadi. 


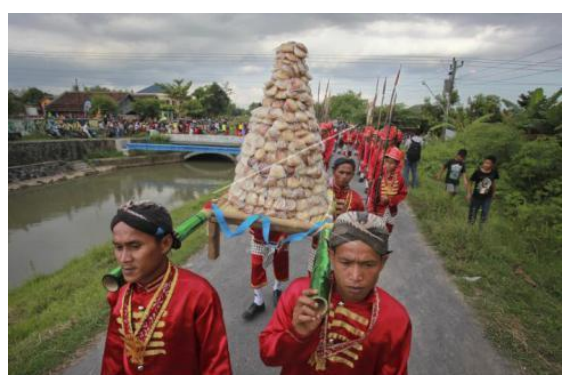

Figure 1. Carrying Gunungan in Kirab at the Tuk Traditional Ceremony.

\subsection{The Age of Hyperreality}

Hyperreality is the meaning to make sense of how the consciousness defines true reality in the world where the diversity of media can form and select real events or experiences. Jean Baudrillad mentions the notion of simulation and simulacra in discussing the concept of hyperreality [4]. According to him, simulation is a state in which representation or depiction of an object becomes more important than the actual object, while simulacra refers to a duplication which never exists in the first place, resulting in a blurry line or distinction between the duplications and the facts. Baudrillard also points out that people today live in a world that is increasingly full of information, yet simultaneously deprived of meaning.

\subsection{Jean Francois Lyotard's Semiotics}

Semiotics is one of the disciplines which study signs. The term "sign" itself can be defined as something which consists of other components or adds a different dimension on a certain object. According to Saussure in Berger, signs are made up of two elements, namely signifier and the signified [3]. Signifier refers to something materialistic which can be sensed vividly, while the signified is the human concept of thought on a sensed object. This human concept of thought is something that is open to interpretations. The study of signs can also be examined through the perspective of Jean Francois Lyotard. Lyotard was a French philosopher who became well-known with his idea on the rejection toward the Grand Narrative which has the legitimacy to unite, is universal, and total toward the social life. Lyotard's rejection toward the assimilation of cultures and apply the entire social layers with one system. Lyotard considers this as harmful as it will impact on the loss of the diverse people's tradition, which prompts him to prefer little narative. Little narrative, according to Lyotard, refers to the social life which is full of diversity such as myths, mystical powers, people's wisdom, and other forms of a group of community which is not owned by other community groups [9].

Signs in social life, according to Lyotard, have three components, i.e. fragmentation in little narrative, as well as the game between language and the arts in the social relation. Firstly, fragmentation in little narrative of Kirab at the Tuk Si Bedug Traditional Ceremony is in the form of relation between people in a certain space and time which creates meaning or a myth. Secondly, the language game in Kirab at the Tuk Si Bedug Traditional Ceremony is carried out in the way in which each question is defined according to the regulations which determine the nature and function value. According to Lyotard, the sublime language game has brought us beyond the boundaries of thoughts where judgment must recognize the unsuitability of the resources, or the lack of agreed upon criteria to deal with the cases which go beyond all boundaries of 'rational' judgment that have been regulated [5] The form of language brings the thoughts outside the human rational mind in Kirab at the Tuk Si Bedug Traditional Ceremony. Thirdly, for Lyotard, art in the social relation is the same as philosophy, in the sense it has no relation with the issues of meaning, identity and truth. The energy of art is a drive that is uncontrollable by the rational mind or consciousness. Art also has an explosive power which is capable to create events [9]. Therefore, this paper attempts to focus on the aspects that can create the spontaneity of the event in Kirab at the Tuk Si Bedug Traditional Ceremony.

\section{RESEARCH METHODOLOGY}

This study used the qualitative method. According to Bogdan \& Taylor in Meleong, the qualitative method is a research procedure that is based on and generates descriptive data in the form of written data [6]. The approach used is the semiotic approach of Jean Francois Lyotard. There are three things to focus on in this research. The first one is the fragmentation in the Kirab narrative in the Tuk $\mathrm{Si}$ Bedug Traditional Ceremony, which refers to the forms of relationships between people in a certain space and time that creates meaning or myths. This paper will discuss these forms of relationship in the context of local creativity. The second element is the language game in Kirab at the Tuk Si Bedug Traditional Ceremony. The concept of language game is carried out in a way that each statement can be defined according to the rules that determine its nature and its function value. According to Lyotard, 
the sublime language game has taken us beyond the limits of thinking where judgments must acknowledge the inadequacy of its resources, or the lack of mutually agreed upon criteria, to deal with cases that go beyond all the limitations of 'rational' judgment that have been set [9]. Thus this paper intends to discuss all forms of language that lead to thoughts beyond the human rational sense in the Kirab event at the Tuk Si Bedug Traditional Ceremony. The third one is the artistic value in kirab. To Lyotard, art and philosophy have nothing to do with the matters of meaning, identity and truth. The energy of art is an impulse that is not controlled by reason or consciousness. Art also has an explosive power capable of creating events [9]. For these reasons, the paper aims to focus on the aspects that make spontaneity of the event in the Kirab at the Tuk Si Bedug Traditional Ceremony. Next, this paper discusses the tradition from the point of view of hyperreality to discuss in depth the impact of media use and the society's consumptive behavior on tradition. The data used in this study are primary data and secondary data. Primary data is the result of direct interviews with local community leaders. Meanwhile, secondary data is obtained through a literature study involving relevant journals, books and articles.

\section{FINDINGS}

\subsection{Fragmentation in the Little Narrative of Kirab at the Tuk Si Bedug Traditional Ceremony}

According to Lyotard, little narrative is all the aspects of social life which have mythical, spiritual, and ideological values which cannot be applied generally [8]. There are many fragments of forms of action or relationship of a small group which are believed to generate myths or stories which until today are familiar among the public in Kirab at the Tuk Si Bedug Traditional Ceremony. First, it is widely known that Kirab is held on a Friday Pahing between June and August since ages ago. The relationship or fragmentation can be seen in the determination of the time of Kirab on a Friday Pahing and the months between June and August. Friday Pahing is the pasaran day in Grogol market. The hustle and bustle during a pasaran day are bigger than the regular days. What can also be identified is the sign system, in which the signifier of Kirab at the Tuk Si Bedug Traditional Ceremony is the Friday Pahing between June and August, while the the signified, which also represents the fragmentation of this phenomenon is the Kirab at the Tuk Si Bedug Traditional Ceremony which is held on a Friday
Pahing between June and August, which is related to the origin of Tuk $\mathrm{Si}$ Bedug itself. The local community believes that Sunan Kalijaga was the one who preached Islam in the Margodadi village on a Friday. On the fateful Friday, Sunan Kalijaga was also believed to stick a staff into the ground, from which spring water emerged and was used to wudlu (purifying oneself before prayer). The spring water formed a small pond which was later named the Tuk Si Bedug.

Secondly, the arakan or parade of carrying two gununangan during Kirab at the Tuk Si Bedug Traditional Ceremony, namely gunungan cethil and gunungan wuluwetu. Meanwhile, the social actions that are related to each other and create certain meaning and believed by the community until the present time are ngarak or parading around the gunungan cethil and gunungan wuluwetu, and the community's fighting for and keeping the parts of gunungan until the next year. These fragments can be seen as signifier. Cethil is a specialty food of the Grogol village which is made of rice flour and has a round shape, and can be easily found in the Grogol market. Wuluwetu consists of various kinds of raw vegetable and crops, including caisim, carrots, nuts, etc. These decisions prompt various interpretations by the local community. Interpretation that serves as the signified is identified as the arakan gunungan cethil as the form of prosperity of the community which is signified by their unity, as well as arakan gunungan wuluwetu which is a form of gratitude for the bountiful harvest in Margodadi Village, and storing the crops to last until the next year, which is believed to give them continuous welfare until they hold the Tuk Si Bedug Traditional Ceremony in the next year.

\subsection{The Language game in Kirab at the Tuk Si Bedug Traditional Ceremony}

According to Lyotard, language game refers to no one scientific concept or explanation or theory which can capture the reality in its totality appropriately. There are three types of language, according to Lyotard, i.e. 1) the denotative game, which focuses on the right or wrong aspects of a language and stresses on the facts, 3 ) the perspective game, which focuses on good or bad, fair and unfair aspects to examine the social values within in a society, and 3) the technical game, which focuses on efficiency that is more factual, although value can be taken into account.

Language is a means of communication used among humans to interact through the exchange of linguistic symbols, both verbal and nonverbal [1]. 
According to Charles Sanders Pierce, language refers to signs in human life and may be uttered through oral speech, one's behaviors, and symbols which serve to convey message for another party to accept and understand. In the Kirab at the Tuk Si Bedug Traditional Ceremony, there are many language games.

The first one is the visible signifier, namely gunungan cethil and wuluwetu. In the denotative game, gununangan cethil and wuluwetu has the shape of a mountain containing traditional market snacks such as cethil and raw vegetables. This represents a reality of the gunungan which is seen the way it is. The traditional snack cethil can be eaten immediately and is sweet, while the raw vegetables can be cooked into dishes. However, in the perspective game, gunungan in this context reveals a deeper interpretation than what it seems. Cethil, the sweet and round snack, symbolizes welfare, that is shown by the unity of the community, while the raw vegetables represent the gratitude of the bountiful harvest, as evident by the variety of vegetables added to the gunungan. Next, from the technical game, gunungan cethil and wuluwetu is seen as a signifier in which the form has addressed the the signified which the community interprets as prosperity, unity, and a form of gratitude toward God on the great blessings.

The second one is signifier in Kirab at the Tuk Si Bedug Traditional Ceremony as the intention to obtain blessings. From the denotative game, the the signified, as shown by the end of Kirab with the sharing of the harvest, is a form trying to obtain blessings in the form of cethil and vegetables to be cooked. The blessing is also in the form of joy while watching the Kirab. On the other hand, the language perspective game has a different meaning, in regard to the signifier of Kirab and the the signified of obtaining blessings. The the signified can be understood in a wider context as the community believes in the blessings they obtain from the Kirab which turns into a bigger blessing in the future. This is identified by the belief of the local people in keeping the raw vegetables from the Kirab until the next year's Kirab event. Most people interpret preserving parts of the gunungan harvest as continuous blessings. Next, in the language technical game, the message of kirab has technically addressed the community's way in accepting the objects in their reality. However, when the goods are stored raw vegetables, they are considered inappropriate as it is not efficient in storing raw vegetables in a long period as they will rot and give unpleasant smell and fungi.

\subsection{Art in Kirab at the Tuk Si Bedug Traditional Ceremony}

The energy of art is a drive that cannot be controlled by the rational mind or consciousness. Art also has an explosive power which creates events [9]. The Kirab event at the Tuk Si Bedug Traditional Ceremony itself is art for the audience. In spite of the meanings contained in Kirab, art can be seen by how Kirab can draw the public's attention. Public enthusiasm makes Kirab an unmissable event. The energy, feeling, and though of the community are showing when they see the parade of the uniformed troops marching behind the gunungan. Each individual has their own interpretation on that moment. The feelings that show will burst when the community begins to run toward and fight to get parts of the gunungan cethil and wuluwetu. The moment of fighting for the gunungan gets out of control sometimes and this is also art. The action is full of desire of the people to get parts of the gunungan is a spectacular one. Art can be seen in the action itself as well as the feelings incited. Without realizing it, the community is drowned in the rhythm of getting their hands on the gunungan. There is a great contrasting feeling of trying to get the gunungan while having to fight for it with a crowd who also has the same purpose. There is a feeling of joy for getting the gunungan, but also a sense of loss when it is clear that they may not get any of the gunungan. The visitors who only come to watch may have the feelings of admiration, amazement, joy, and others. The feelings that emerge are different between one individual and another. In general, art in Kirab is present not based on the meaning, the identity of the artists or the truth of the event in the law of nature, but in that context, art is seen as the moment that is present and manages to make feelings burst as the event takes place.

\subsection{Hyperreality in Kirab at the Tuk Si Bedug Traditional Ceremony}

\subsubsection{The Role of Media}

The present era is the millennial era where social media can be accessed in an instant. Social media serves as one of the platforms of distributing information on cultural events, including the Tuk Si Bedug Traditional Ceremony. The social media platforms used include Facebook, Twitter, Instagram, etc. Sometimes the even organizers ask the owner of accounts with a large number of followers to draw the attention of the social media users. Sometimes accounts with a great number of followers repost or share the information to their followers. By only 
using photos that are edited to be more attractive or interesting, media mass advertisements also serve as one of the means to share information to the public. Other media used to give information on traditional events may include banners or billboards on the streets. These types of media are typically edited in such a way with attractive images to draw attention toward the event with interesting catchphrases to attract visitors.

\subsubsection{Consumptive Behavior}

Consumptive behaviors are highly related to the current age of hyperreality. Local governments also get involved to make the event successful by inviting local community figures or leaders to give a welcome speech and lead prayer and throw the ceremonial undhik-undhik (throwing coins as a symbol of sharing welfare with the common people). As a result, many visitors or tourists come to see the celebration of Tuk Si Bedug ceremony, especially during the kirab gunungan. In addition to enjoying the Kirab event, visitors also come to ngalap some good fortune by taking part in the trying to get the gunungan or catch the undhik-undhik. Visitors and the local community believe that getting some part of the raw vegetables and cethil will bless them with great fortune for the next year.

In addition to coming for obtaining blessings, many visitors take pictures and upload them on the social network platforms. This is beneficial to the local government to promote information on the traditional event. The more visitors come and take pictures, the more the regional tradition becomes well-known. In order to make the events merrier, the organizing committee provides more entertainment such as jathilan or kuda lumping, dangdut music event, while also being attended with local figures. Kirab at the Tuk Si Bedug Traditional Ceremony is also one of the moments for the street vendors to make use of the opportunity to obtain fortune by selling street food or children's toys. The increasing number of visitors will also add to the regional revenue. Therefore, at present, the event becomes one of the ways for the local government to obtain revenue, which is a more materialistic way compared to the initial objective of the celebration and preservation of the local culture, as well as a form of honoring Sunan Kalijaga for introducing Islam in the region and giving prayers as a form of gratitude for the prosperity in the area.

\section{CONCLUSION}

Kirab at the Tuk Si Bedug Traditional Ceremony is the main topic in understanding Lyotard's notion on sign system. The signs within the ceremony is evident from the relationship (fragmentation) among the community which incites certain meaning, such as the selection of the date of the event which is in fact related to the story of Sunan Kalijaga in introducing Islam in the Margodadi village. The signs can be seen from the language game during the traditional ceremony. Language does not necessarily refer to speech or utterance, as it also signifies human behavior which suggests some type of message. For instance, unity is represented by cethil, a round snack with no edges. The round shape with endless line and the mixed dough represents unity. Art in Kirab can be seen from the enthusiasm and spontaneity of the local community who fights to get gunungan. Kirab at the Tuk Si Bedug Traditional Ceremony in hyperreality depicts how media has an important role in distributing information to the community, and that Kirab has a consumptive implication for the visitors.

\section{REFERENCES}

[1] Amri, Yusni Khairul. Bahasa Indonesia: Pemahaman Dasar-dasar Bahasa Indonesia [Indonesia Langage: Understanding the Basics of Indonesia Language. Atap Buku: Yogyakarta (2015).

[2] Bastomi, Suwaji. Gelis kenal wayang [Gelis Knows Wayang]. IKIP Semarang Press, 1992.

[3] Berger, Arthur Asa. Pengantar Semiotika: Tanda-tanda dalam Kebudayaan Kontemporer [Introduction to Semiotics: Signs in Contemporary Culture]. Tiara Wacana, 2010.

[4] Baudrillard, Jean. Simulacra and simulation. University of Michigan press, 1994.

[5] Lubis, Akhyar Yusuf. Postmodernisme: teori dan metode [Postmodernism: The theory and method]. Jakarta: Rajawali Pers (2014).

[6] Moleong, Lexi J. Metode Penelitian Kualitatif [Qualitative Research Methods], Bandung: PT Remaja Rosdakarya, (2002).

[7] www. kbbi. web.id d accessed on The 16th September 2020. 
[8] Sarup, Madan. Posstrukturalisme dan Posmodernisme: Sebuah Pengantar Kritis [Poststructuralism and Postmodernism: A Critical Introduction]. Yogyakarta: Jendela (2003).

[9] Umanailo, M. Chairul Basrun, and Chairul Basrun. Postmodernisme dalam pandangan jean francois lyotard [Postmodernism in the view of Jean Francois Lyotard]. (2018). 